\title{
Development Difficulties and Countermeasures of Small Loan Companies__take Guangdong Province for example
}

\author{
Hui Liu' ${ }^{1}$ Jianghuai Ling ${ }^{2}$ \\ ${ }^{1,2}$ School of Economics and Management, South China Normal University, Guangzhou Guangdong, 510632, \\ China
}

Keywords: Guangdong Province, Small loan companies, Difficulties and countermeasures.

\begin{abstract}
After nearly 10 years of development,the development of small loan companies has achieved some success,but there are still many problems.Especially affected by the economic downturn in the past two years, the development of small loan companies are facing increasingly prominent problems and encountered a bottleneck. Based on the research of small loan companies in Guangdong Province,this paper combed the present situation, analyzed the problems of its development, and put forward some countermeasures to promote the development of small loan companies.
\end{abstract}

\section{Introduction}

Based on the topic of the Guangdong provincial science and Technology Department---- Research on financing system of small and medium sized enterprises in Guangdong, from January 2015 to December 2015, the authors made an investigation on the development of small loan companies in Guangdong Province, in the form of an informal discussion of the financial work bureau and small loan companies. We found in the survey that the development of small loan companies in Guangdong Province has encountered a great bottleneck in the present_—Banks require small loan companies to repay the loan in advance; and with the economic downturn, the borrower has difficulty to repay the loan on time; the legal positioning of the small loan companies is not clear; heavy tax burden and so on . Relevant government departments give positive attention to the development of small loan companies,but there is still no breakthrough to solve the substantive problems of the small loan company.

The exiting research of small loan company mainly focuses on risk control, development mechanism, financing channels, the legal status of small loan companies and so on.Shi Huihong et al.(2016) argues that the current credit factory model, credit manager nanny mode and bank credit are not suitable for China's small loan companies, the reason lies in the absence of social credit system, these three models will lead to a small loan company internal departments jointly fraud, the moral hazard problem is particularly prominent.Zhong Meiying (2015) believes that microfinance companies facing dual constraints of system and capital, the fuzzy legal status of small loan companies lead to regulatory virtualization, and it also causes the nature of the business is not clear, thus lead to the financing difficulties. Yang Linsheng et al.(2014) argues that microfinance companies face many institutional constraints in practice, these constraints seriously restrict the sustainable development of small loan companies, so we need to improve the system of top-level design of the small loan companies, and fully release the system performance.Wu Zhi (2013) thinks ithat the government should learn from international experience, and actively promote small loan companies to enter in the bond market financing pilot, crack the small loan company financing problems.Tang Bi (2012) believes that small loan companies are mainly facing the problems of the system and business, the government should not only relax its regulation, but also need to improve the financing channels. All above are for the whole country, but in reality, due to the differences in economic development between provinces and cities, the specific problems faced by small loan companies are also different,there is no literature in-depth research on the development of small loan companies in Guangdong Province, analyze the bottleneck of the development of small loan 
companies in Guangdong province and give specific countermeasures and suggestions. Based on the investigation and Research on the development of small loan companies in Guangdong province and the relevant data of the past five years, this paper analyzes the current situation and existing problems of small loan companies in Guangdong Province, and gives some suggestions to promote the healthy and orderly development of small loan companies in Guangdong province.

\section{The development of small loan companies in Guangdong}

\section{The overall operation of small loan companies}

2015, there are 378 small loan companies in Guangdong (excluding Shenzhen, the same below), the total registered capital is 51.14 billion yuan, with an average of $\$ 140$ million per registered capital. Private companies accounted for more than 90\%. From table 1 ,in the past 5 years, the number of small loan companies in Guangdong has increased significantly, with an average annual increase of 36.4. Registered capital increased by an average of 6 billion 28 million yuan per year.

Table 1. The overall profitability of small loan companies in Guangdong Province from 2011 to 2015

\begin{tabular}{|c|c|c|c|c|c|c|c|}
\hline Year & $\begin{array}{c}\text { Number of } \\
\text { small loan } \\
\text { companies }\end{array}$ & $\begin{array}{c}\text { Total } \\
\text { registered } \\
\text { capital } \\
\text { (Billion } \\
\text { Chinese } \\
\text { yuan) }\end{array}$ & $\begin{array}{c}\text { Average } \\
\text { registered } \\
\text { capital (Billion } \\
\text { Chinese yuan) }\end{array}$ & $\begin{array}{c}\text { Operating } \\
\text { income } \\
\text { (Billion } \\
\text { Chinese } \\
\text { yuan) }\end{array}$ & $\begin{array}{c}\text { Net profit } \\
\text { (Billion } \\
\text { Chinese } \\
\text { yuan) }\end{array}$ & $\begin{array}{c}\text { Annual growth } \\
\text { rate of } \\
\text { operating } \\
\text { income }\end{array}$ & $\begin{array}{c}\text { Annual } \\
\text { growth rate } \\
\text { of net profit } \\
\text { (\%) }\end{array}$ \\
\hline 2011 & 196 & 210 & 1.07 & 14.74 & 6.28 & & - \\
\hline 2012 & 211 & 325 & 1.54 & 30.39 & 12.48 & 106 & 98.73 \\
\hline 2013 & 288 & 367 & 1.27 & 35.6 & 14.6 & 17.14 & 16.99 \\
\hline 2014 & 352 & 481.2 & 1.37 & 52.7 & 19.8 & 32.45 & 35.62 \\
\hline 2015 & 378 & 511.4 & 1.35 & 49.8 & 14 & -5.50 & -29.29 \\
\hline
\end{tabular}

It can be clearly seen from table 1,small loan companies in 2015 show "three drop"-drofit decline、 return on capital decline and delivery ratio decline. In 2015, the Guangdong small loan industry's operating income is 4.98 billion yuan, and drop $11.4 \%$ compared with 2014 ; the net profit is 1.4 billion yuan, and drop 29.3\% compared with 2014; the loan balance is 47.75 billion yuan, and drop 3.1 billion yuan compared with the end of 2014,fell 6.1\%. Affected by the overall economic downturn, the industry average return on capital is 3.03\%, fell $2.5 \%$ compared to the previous year. Small loan company financed 4.74 billion yuan from banks, small reloan companies and other institutions in 2015, together with a registered capital of 51.14 billion yuan and undistributed profits, the loanable funds reach more than 600 billion yuan. Affected by the downturn in the macroeconomic situation, the province's small loan companies generally tightened lending, the cumulative total loans only 53.53 billion yuan, by the end of 2015 , the loan balance is 47.75 billion yuan, lending ratio is less than $80 \%$.Net profit growth rate is $-29.29 \%$ in 2015, reflecting the development of small loan companies difficult. 


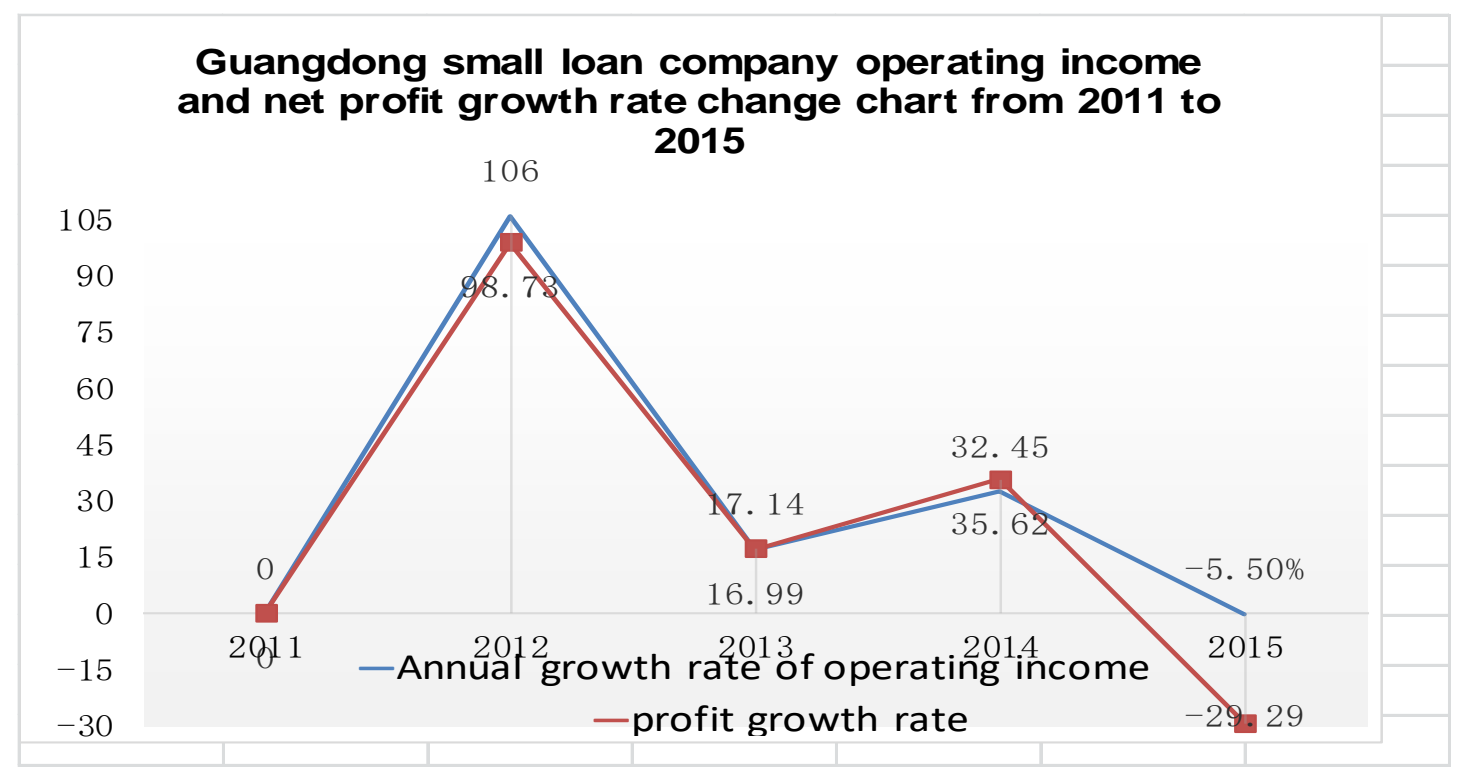

Fig. 1. Guangdong small loan company operating income and net profit growth rate change chart from 2011 to 2015

It can be seen from chart 1,small loan companies' net profit growth reached its peak in 2012 ,then decreased year by year.Net profit growth is less than the growth rate of revenue growth, while the decline in net profit is far greater than decline in operating income. According to accounting formula,net profit equals to operating income minus tax, the amount of tax will affect the company's net profit, the range of operating income and tax changes impact the range of net profit change. With operating revenue growing, tax will increase, while tax increase is greater than the growth rate of operating income, it will lead to the growth rate of net profit less than the growth rate of operating income; while operating income decreases, the decrease in net profit is less than the reduction in operating income, and it will lead to a decline in the magnitude of net profit greater than the magnitude of the decline in operating income.To some extent, it also reflects the tax burden of small loan companies. The following data will be used to illustrate the relationship between tax and turnover.

\section{The current situation of Guangdong small loan company' tax payment}

Guangdong small loan industries’ operating efficiency declined in 2015,operating income is 4.98 billion yuan, 11.4\% lower than in 2014;pay tax 850 million yuan.

Table 2. Guangdong small loan company tax table from 2011 to 2015

\begin{tabular}{|c|c|c|c|c|c|}
\hline Year & $\begin{array}{c}\text { Operating } \\
\text { income (Billion } \\
\text { yuan) }\end{array}$ & $\begin{array}{c}\text { Tax amount } \\
\text { (Billion yuan) }\end{array}$ & $\begin{array}{c}\text { Annual growth } \\
\text { rate of operating } \\
\text { income (\%) }\end{array}$ & $\begin{array}{c}\text { Annual growth rate of } \\
\text { tax payment (\%) }\end{array}$ & Tax revenue ratio(\%) \\
\hline 2011 & 14.74 & 2.75 & - & - & 96.36 \\
\hline 2012 & 30.39 & 5.4 & 106 & 24.07 & 18.66 \\
\hline 2013 & 35.6 & 6.7 & 17.14 & 46.27 & 18.82 \\
\hline 2014 & 56.21 & 9.8 & 32.45 & -1.33 & 17.43 \\
\hline 2015 & 49.8 & 8.5 & -11.4 & 17.07 \\
\hline
\end{tabular}

It can be seen from table 2, the growth rate of Guangdong small loan company's operating income is very fast,the annual growth rate is $51.86 \%$ from 2012 to 2014,operating income grows $106 \%$ in 2012 compared to 2011, fell 11.4\% in 2015 compared to 2014. The annual average growth rate of tax is $55.57 \%$ from 2012 to 2014, and fell 1.33\% in 2015. The average annual growth rate of tax exceeds the average annual growth rate of 3.71 percentage points, while when operating income declines, the reduction in tax revenue is less than 10 percentage point reduction in operating income.To some extent, it also reflects the tax burden on small loan companies, the proportion of tax revenue accounted for up to $18 \%$, far higher than the level of interest rates in the financial sector, up to $6 \%$. 
The high tax burden crowds out the small loan companies’ profit margins, increased burden of small loan companies, which lead to the small loan company has to maintain a higher lending rate in order to maintain a certain profit margin to ensure basic survival, so the high tax burden also reduces the competitiveness of small loan companies.

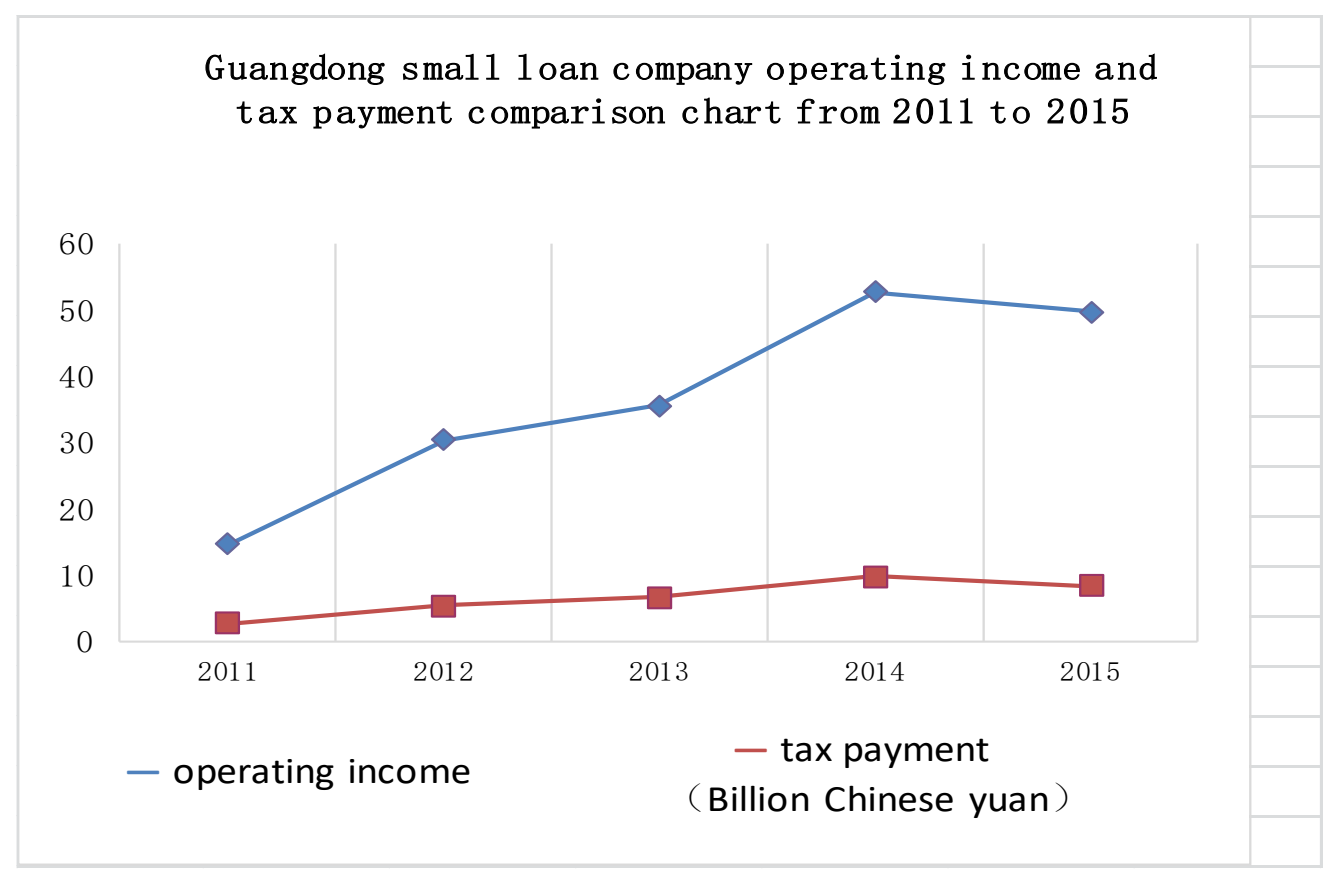

Fig. 2. Guangdong small loan company operating income and tax payment comparison chart from 2011 to 2015

It can be seen from chart2, the amount of tax increase of small loan companies is greater than the decline of tax revenue, a sharp drop in operating income didn't result in a significant reduction in tax revenue.Compared to operating income, tax revenue growth is relatively fast and the decline is more slower, which means that regardless of operating income is high or low, the tax burden is at a relatively high level, the tax burden of small loan companies.

\section{The basic situation and the current situation of bank financing of Guangdong small loan companies}

The number of small loan companies increased in 2015,while the overall lending fell sharply, each small loan company has only 13 million yuan in lending on average, ranked second to last during these five years, and only more than 1 million yuan in 2011.

Table 3. Guangdong (excluding Shenzhen) small loan company leading and loans table from 2011 to 2015

\begin{tabular}{|c|c|c|c|c|c|c|}
\hline Year & $\begin{array}{c}\text { Number of } \\
\text { small loan } \\
\text { companies } \\
\text { cegistered } \\
\text { capital } \\
\text { (Billion } \\
\text { yuan) }\end{array}$ & $\begin{array}{c}\text { Loan amount } \\
\text { (Billion } \\
\text { yuan) }\end{array}$ & $\begin{array}{c}\text { Total bank } \\
\text { financing } \\
\text { (Billion } \\
\text { yuan) }\end{array}$ & $\begin{array}{c}\text { The average } \\
\text { number of loans } \\
\text { per each small } \\
\text { loan company } \\
\text { (Billion yuan) }\end{array}$ & $\begin{array}{c}\text { The average } \\
\text { amount of loans } \\
\text { accounted for the } \\
\text { proportion of } \\
\text { registered capital } \\
\text { (\%) }\end{array}$ \\
\hline 2011 & 196 & 210 & 268.39 & 24 & 0.12 & 11.21 \\
\hline 2012 & 211 & 325 & 416 & 29 & 0.14 & 9.09 \\
\hline 2013 & 288 & 367 & 687 & 46.97 & 0.16 & 12.60 \\
\hline 2014 & 352 & 481.2 & 922.3 & 60.7 & 0.17 & 12.41 \\
\hline 2015 & 378 & 511.4 & 535.3 & 47.4 & 0.13 & 9.63 \\
\hline
\end{tabular}

It can be seen from table 3,the total amount of small loan companies in Guangdong reached its peak in 2014 of 92.23 billion yuan, but in 2015 the rate dropped to 53.53 billion yuan, down by 
41.96\%, and compared to 2013,the rate declined 22.08\%.The development of small loan companies in 2015 almost returned to the level of 2012.The entire industry has shrunk dramatically, it also reflected the development of small loan companies into the winter period.

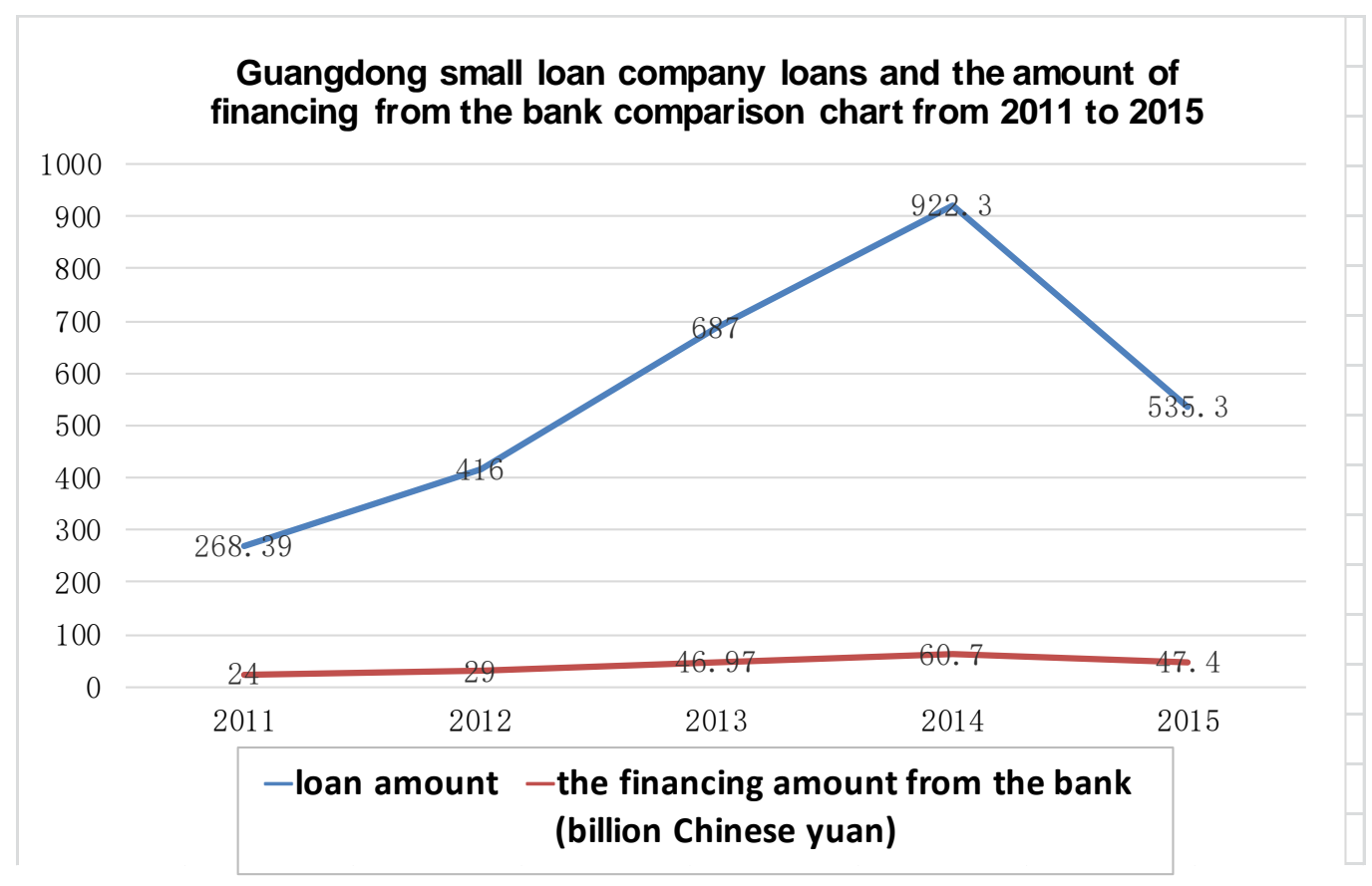

Fig. 3. Guangdong small loan company loans and the amount of financing from the bank comparison chart from 2011 to 2015

It can be seen from chart 3,over the past five years, the amount of small loan companies from bank financing has not increased with the development scale,the proportion of the amount of financing from the bank accounted for the amount of the loan amount does not exceed 10\%,the highest ratio was $8.94 \%$ in 2011, the lowest ratio in 2014 was 6.58\%,each small loan company obtained the average amount of financing from the bank between 0.12-0.17 billion Chinese yuan, which just accounted for between $9 \%$ to $13 \%$ of the registered capital,far from reaching the policy set the maximum amount of loans from the bank, which does not exceed $50 \%$ of the registered capital,that is, there is a lot of financing space for small loan companies, the key is how to finance. It can also be seen from chart 3 that regardless of the development of small loan companies in a period of prosperity or difficult period, the bank has not given adequate financing support, and more than $95 \%$ of its loan funds comes from its own funds. But at the same time, because of policy limit — the small loan company loan can only loan but save, it results the financing channels for small loan companies quite limited,highly depends on the bank, and the ability to get a loan from the bank is entirely up to the bank. Coupled with the development of the industry has not reached a certain scale, there is no large-scale small loan companies,and it can not be achieved the equal status with the bank in the negotiations, the bank is in a position of absolute superiority in the loan. At the same time, coupled with the imperfections of the capital market, small loan companies can choose a small number of financing channels, financing options can be quite limited, further strengthened its dependence on banks.

\section{Guangdong small loan companies operating risk highlights}

Guangdong small loan companies operating risk highlighted in 2015, the balance of non-performing loans and non-performing loan ratio continued to double up trend, the highest rate of non-performing loans reached nearly five years, the industry will greatly increase the risk management. 
Table 4. Guangdong small loan company bad loans and the average loan interest rate from 2011 to 2015

\begin{tabular}{|c|c|c|c|}
\hline Year & $\begin{array}{c}\text { Bad loans (ten thousand } \\
\text { Chinese yuan) }\end{array}$ & Bad loan ratio (\%) & $\begin{array}{c}\text { the industry average loan } \\
\text { interest rate (\%) }\end{array}$ \\
\hline 2011 & 6280 & 0.46 & 15 \\
\hline 2012 & 7856 & 0.36 & 15.5 \\
\hline 2013 & 20266 & 0.56 & 21.48 \\
\hline 2014 & 32280 & 0.63 & 13.93 \\
\hline 2015 & 133658 & 2.8 & \\
\hline
\end{tabular}

It can be seen from table 4,the non-performing loans of Guangdong small loan companies amounted for 1.34 billion yuan, and 1.1 billion yuan more than in 2014; non-performing loan rate of 2.8\%, 2.17 percentage points higher than in 2014; the average lending rate fell 7.55 percentage points compared to 2014. With the business shrinking, the average loan rate has dropped significantly, which means that the profit margin of small loan companies fell sharply, and the living space has been severely squeezed. In addition, the non-performing loan ratio rose sharply - 4.4 times higher than in 2014,the rise was the highest in nearly five years.

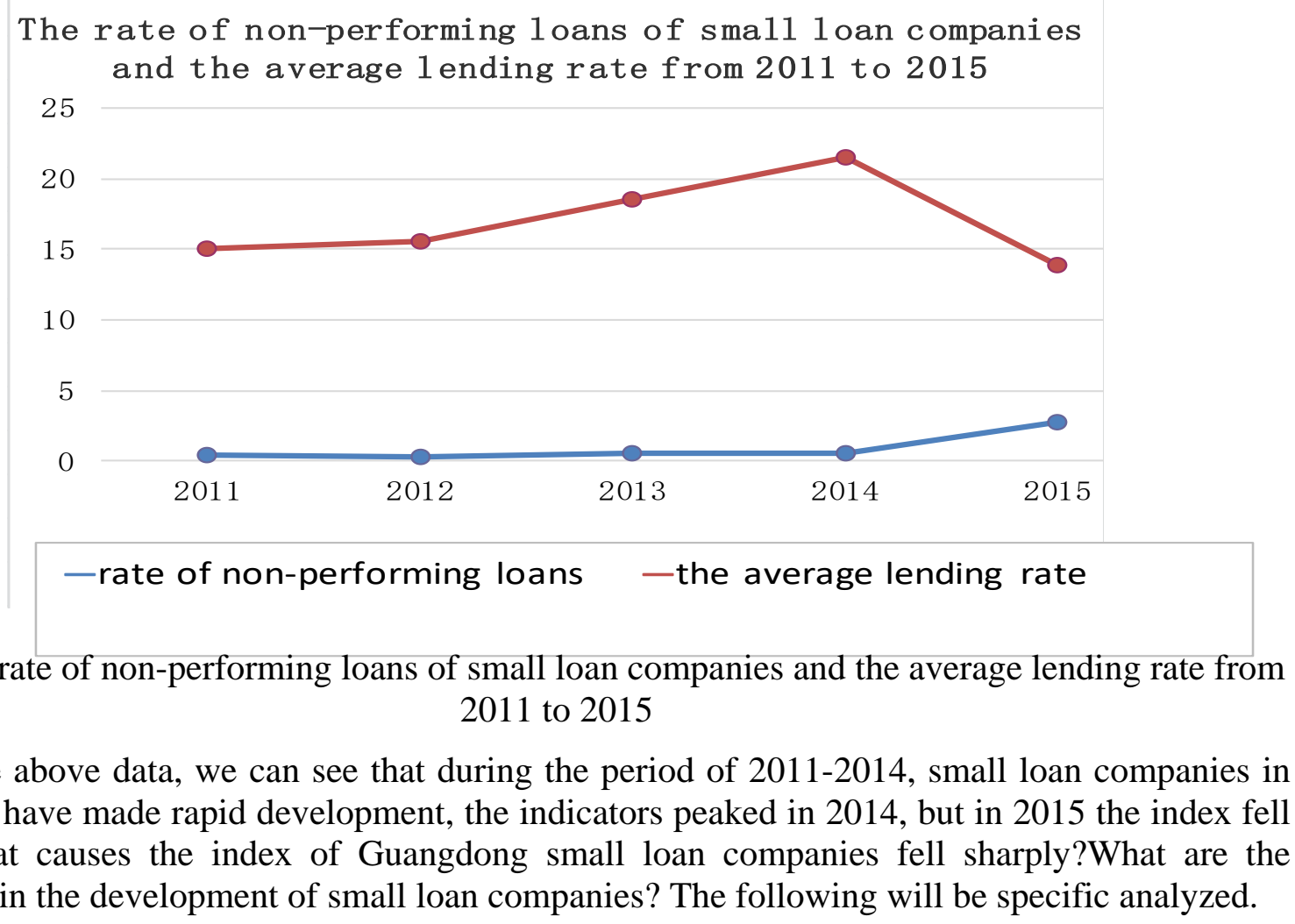

Fig. 4. The rate of non-performing loans of small loan companies and the average lending rate from 2011 to 2015

From the above data, we can see that during the period of 2011-2014, small loan companies in Guangdong have made rapid development, the indicators peaked in 2014, but in 2015 the index fell sharply.What causes the index of Guangdong small loan companies fell sharply?What are the bottlenecks in the development of small loan companies? The following will be specific analyzed.

\section{The bottlenecks in the development of Guangdong small loan companies}

By visiting Foshan, Zhongshan, Zhuhai, Jiangmen, Qingyuan and other places, discussed with the local finance bureau and local small loan companies, we found that the development of small loan companies have encountered a larger bottleneck at present, a lot of small loan companies for future development is full of confusion and worry, mainly present in following aspects:

\section{Affected by the economic downturn, the industry risk increased}

Economic situation is grim in 2015,small and medium enterprises bear the brunt of the impact, some industries of small and micro enterprises operating meet difficulties, funding problems, gradually increasing the difficulty of repayment,led to a lot of small loan companies for risk control considerations, tightening the scope of business, lending more cautious. For some high-risk small and micro enterprises , a large number of small loan companies out of caution, early recovery of the loan business, while reducing the industry's business loans.Meanwhile the bank has issued a request for 
early repayment of loans with its strong position, which led to small loan companies had to withdraw the loan to the enterprise in advance, adversely affected their own reputation.

At the same time,due to the economic downturn, the bank fully tightened loans to small loan companies, small loan companies have difficulties in external financing.In the course of the investigation, Guangdong small loan companies generally respond to a narrow range of sources of funding,mainly use their own funds to lend, fewer and fewer banks are willing to cooperate with small loan companies,even the National Development Bank has gradually recovered the financing of small loan companies, did not continue to give new financing support.

\section{Heavy tax burden}

During my investigation and study,small loan companies respond that they born heavy tax ,they need to bear the income tax, business tax and other taxes,the average tax rate is around 29\%.they can bear the high tax burden in good condition,but in the current business scope narrowed, many small loan companies can not afford such a high tax.Small loan companies believe that the main reason for the high taxes is that the government's positioning of small loan companies is not clear.In the people's Bank of China and other departments promulgated the "financial industry enterprise type standard provisions", the small loan company is designated as a non monetary banking services financial enterprise;But in the actual operation, the CBRC, the tax department did not make the corresponding change, small loan companies still do the local financial supervision, especially to pay tax according to the general industrial and commercial service companies, several times higher than commercial banks.In addition, the micro credit company's identity is not clear, but also led to its multi-sectoral, multi-level supervision, but when encounter problems ,they can not find a Department to solve problems.

\section{Industry preferential policies difficult to implement}

It will take a long time for the center policy to be implemented.In November 2014 the government issued a document that a small loan company can not to more than two banks into the capital of not more than $50 \%-100 \%$ of funds for loans.But now almost all banks are refusing to lend to small loan companies, but also means that small loan companies do not have any leverage at all, there is big gap between policy and reality.On December 8, 2014, Vice Premier Ma Kai, the State Council held a national teleconference on the development of financing guarantee industry. The meeting stressed that the local government should take measures to be willing to invest, financing guarantee institutions funded by the government to set up more holding shares, perfecting the guarantee system, through tax incentives and risk compensation policies and measures to increase support.Banks should take the initiative as, improve the mechanism of cooperation and risk sharing mechanism, reduce the cost of social financing, better serve the real economy.Small loan companies and financing Guarantee corporation consider this meeting as the industry's spring breeze, winter is about to pass, but by June 2015, nearly six months have passed, and did not feel the policy landing.

\section{Policy funds for small loan companies is lack}

The small loan company loan object is mainly Small and micro businesses, in the current credit system is not perfect, Small and micro businesses lack collateral, financial information is not public, the risk they bear is more greater than other financial institutions.Therefore, all countries in the formulation of policies for small loans, in addition to the design of the system, but also set up for SMEs risk compensation projects.Guangdong province organized relevant units to complete joint audits of 158 small loan companies, 5 banks, 1 financing Guarantee corporation risk compensation special fund application materials, a total of $\$ 44$ million 20 thousand Chinese yuan to fund risk compensation funds in 2014, but this number is less than $1 \%$ of the loan balance of hundreds of billions of small loan companies, its effect is very little.Guangdong Province organized relevant units to complete the risk compensation special fund of 173 small loan companies, 3 banks, a total of 48 million 920 thousand Chinese yuan in 2015 , only increased by 11.13 percentage points compared to 2014, can not play the role of risk compensation. 


\section{Faced with severe competition,their own advantages lost gradually}

Under the guidance of national policy,the traditional financial institutions gradually expand the small and micro enterprises in the financial services sector, many banks set up small and micro enterprises in the service window, to a certain extent, robbed a relatively good quality customer.Meanwhile , the rise of township banks also seize part of the "three rural" customers. These all lead the small loan companies face the more and more lower quality customer groups, the business risk is growing.In addition, with the development of Internet banking and other emerging financial formats, especially the P2P financing platform, squeezing the natural person of small loan company customer service, therefore, small loan companies face more and more competition pressure.

\section{Solving countermeasures}

\section{Strengthen the supervision of small loan companies to guard against the risk of the industry}

At present, the regulation of small loan companies is still scattered in all levels of the supervision of the Municipal Finance Bureau,the survey also found that the human resources of most City Financial Bureau is limited, they have no more energy to take account of the supervision of small loan companies, only in accordance with the higher order to collect relevant data of small loan companies, did not give a comprehensive supervision on the development of small loan companies. Therefore, the government should strengthen the supervision of small loan companies from the following aspects: First, the government should set up a professional supervision team, to strengthen the development of small loan industry, improve the quality of small loan companies, improve the credibility of the industry; Second,the government needs to develop a clear regulatory indicators and evaluation indicators for small loan companies, to strengthen the assessment of small loan companies,grasp of the development of small loan companies in time,identify anomalies and give timely attention;Third,strengthen the micro credit company's credit rating,regular rating of small loan companies through third parties,so as to improve the credibility of small loan companies and improve the quality of the industry as a whole.

\section{Increase policy support for small loan companies}

Research found that the main problems of small loan company is two:First, the tax is too high;second,the future development prospects is uncertain.About the tax,first, the government should give small loan company clear positioning, if positioning in the quasi financial institutions,tax should be levied different from ordinary enterprises,the tax rate should be in the middle of the tax rate between the general enterprise and the financial industry.For the path of development of small loan companies,the state should be clear to the size of small loan companies to what extent, to meet the requirements of what can be turned into a private bank, engaged in formal financial services, to stimulate the enthusiasm of small loan companies.In addition, due to the long engaged in small business loans, small and medium-sized enterprise customers will accumulate more, even engaged in the bank, service object will also give priority to have old customers, there are more sources of funding for small and micro enterprises to provide financing services.

\section{Broaden the financing channels of small loan companies and set up adequate risk compensation funds}

Narrow financing channels restrain the development of small loan companies,it can be clearly seen from the data in this article,small loan companies mainly rely on their own funds, the proportion of bank financing is quite low.In the small loan company loans, the bank is taking a very cautious attitude, especially in the past two years. Therefore, the government should set up adequate risk compensation funds to eliminate bank loans to small loan companies doubt,help banks to share part of the risk, promote cooperation between banks and small loan companies,enhance the ability of small loan companies to external financing.Therefore, it is necessary to set up and improve the proportion 
of the risk compensation according to the ratio of the loan amount of the small loan company,so that it can really play a role in risk compensation.In addition, government can also set up bonus funds, according to the number of loans and the small and micro enterprises they service to give appropriate incentives to improve the enthusiasm of small loan companies.

\section{Set up a clear policy evaluation indicators to strengthen the implementation of the policy}

Research also found that many of the central policy is good, but the implementation of the policy is long and uncertain.Therefore, in addition to formulating policies, the government should set up clear policy evaluation indicators, take effective measures to strengthen the implementation of the policy.First, setting up a clear policy indicators during the setting process of policy, which can used to compare the actual results of the policy to the expected results of the policy, analysis whether the policy has achieved the desired objectives;Second,the government can invite third parties to conduct research on the implementation of the policy, through field visits to relevant companies, to collect first-hand information, analysis the problems encountered in the operation of policy, objective to evaluate the actual results of policy operation and propose improvement measures; Third, introduced the implementation of the policy into the assessment system,to assess the effectiveness of the implementation of the relevant departments; Forth, specify the time period for policy implementation, identify the responsible person for each implementation phase, employ accountability mechanism, informed the implement policy and make correction and inspection within a fixed period.

\section{Small loan companies need to highlight their own characteristics, to gain a place in the competition}

Facing economic downturn and intensified competition in the financial sector,small loan companies should standardize their management and operation, and analyze their own characteristics, optimize service.First, implement standardized management, improve their management level and management ability;second,foster professional personnel to create a professional team, enhance their brand image;Third,refine the service objectives, use the geographical advantages, combined with their own understanding of the local industry, choose a certain industry or a supply chain to set up long-term and in-depth cooperation and establish a strong customer base.Forth,actively play "short, frequency, fast" advantage, complete customer service, enhance the communication with customers, grasp the customer's financial needs at the first time, according to customer demand amount, make the special financial services, to help them achieve maximum benefits;Fifth,reduce dependence on banks and explore new financing models. Small loan companies need to actively explore the source of funds, not just rely on bank loans.At present, the Guangdong provincial government allow small loan companies finance through capital market, small loan companies should enhance their own strength to achieve the basic conditions to the capital market financing according to the relevant requirements, seize the opportunity to become bigger and stronger.

\section{Reference}

[1] Zhong meiying.2015 sixteenth.Research on the sustainable development of small loan companies under the Dual Restriction of system and capital, Economic Research Guide.

[2] Yang linsheng,Yang decai.2014 second.Institutional constraints and Countermeasures for sustainable development of small loan companies, economic issue.

[3] Wuzhi.2013 tenth.Crack the small loan company bond market financing problems, Financial Market Research.

[4] Shi huihong,2016 third.Liming.Research on the moral hazard in the business process of small loan company, Business economic research.

[5] Wang ziwei.2015 seventh.Dilemma and solution: the challenge of Zhejiang small loan company and its institutional bottleneck, Zhejiang Finance. 